\title{
Közönségkapcsolati lehetőségek az MNL Szabolcs-Szatmár-Bereg Megyei Levéltárában
}

\author{
PR Opportunities for MNL SZSZBML
}

\section{KUJBUSNÉ MECSEI É.}

levéltár-igazgató, Magyar Nemzeti Levéltár Szabolcs-Szatmár-Bereg ?egyei Levéltára,

kujbusne.mecsei.eva@mnl.vog.hu

A megyei levéltáraknak napjainkban már nem csak a források őrzése, hanem azok megismerésemegismertetése, a helytörténeti kutatás segítése, a lokálpatriotizmus erősítése is feladatává vált, ami megkövetelte a nyitást, a különböző közönségkapcsolati formák kialakítását.

A vármegye levéltára évszázadokon át a „titkok zárt tára” volt. A levéltárat képező utazóládát, benne a nemesi közgyülés jegyzőkönyveit, ítéleteit és a birtokpereket kezdetben az alispán őrizte. Amikor már a megszaporodott iratok kinőtték a ládát, akkor a jól védhető várak egyikében találtak egy szobát számukra, ahonnan a 18. századtól felépült megyeházákba szállították át a mind több iratot magába foglaló levéltárat. Ettől kezdve gyakran előkerült a rendezés ügye a közigazgatás és igazságszolgáltatás számára fontos régi adatok előkeresése miatt. Az iratokat előbb a nótárius, majd a megbízott levéltárnok kezelte. Bár a 20. század elején már néhány levéltárba betértek a tudományos kutatást végző történészek közül a forrásokat fontosnak tartók, de a hely-, család-, származás-, nemességtörténet iránt érdeklődőknek inkább kikereste az adatokat a levéltáros, mert a nyilvános kutatáshoz nem volt eléggé rendezett, segédletelt az irat, illetve az infrastrukturális körülmények sem voltak biztosítottak, hiszen az iratraktárak mellett legfeljebb egy kis szük szoba állt a levéltáros rendelkezésére.

1950-ben a történelem viharai miatt gyökeresen megváltozott a levéltárak évszázados helyzete. A szomszédos vármegyék nagy része ugyanis a határon túlra került, itt maradt irataikat pedig az önálló intézménnyé vált, állami fenntartásba vett Szabolcs megye levéltárában helyezték el. Az így létrejött Nyíregyházi Állami Levéltár, amely Szabolcs-Szatmár Megyei Levéltár néven 1968-ban megyei fenntartásúként továbbra is a megyeháza szobáiban örizte az iratokat, semmilyen közönségkapcsolatra nem gondolhatott. Sem megfelelő hely, sem elegendő munkatárs nem volt az esetleges kutató fogadásához. A helyzet az 1970-es évek elején fordult jobbra, amikor a levéltár átköltözhetett a Jósa András Múzeummal közös épületbe. Itt a földszinten már tágas könyvtár- és kutatószobát alakítottak ki, amely alkalmas volt kisebb rendezvények tartására is. A közönségkapcsolati terek létrehozása mellett hamarosan jelentkezett a társadalmi igény és formálódott a nyitás lehetősége és szándéka. Ehhez olyan vezetöre volt szükség, mint amilyen dr. Nagy Ferenc volt, aki levéltárossá válása előtt dolgozott tanárként, szakfelügyelőként, múzeumi igazgatóhelyettesként és a megyei müvelődési ház vezetőjeként. Mire a levéltárba jött, addigra megtapasztalta, hogy a szobatudósok kora lejárt, és a levéltár megismertetéséhez ki kell alakítani a közönségkapcsolati formákat. Minthogy az akkori tudományos munkatársak között többen is rendelkeztek tanári diplomával, így három irányban indulhatott a nyitás: a tudományos élet képviselői mellett az érdeklődő lokálpatrióták, valamint a diákok felé.

A kezdeti közönségkapcsolati lehetőségek az évek folyamán bővültek, változtak, módosultak. Egy-egy szakfeladat során mindig újabb és újabb kulturális partnerrel bővül az együttmüködés palettája, míg másokkal a közös munkát követően megszakad a kapcsolat. A munkatársak változásával is módosulnak a programok, a kommunikációs formák. Az infotechnika fejlődése pedig naponta jelent kihívást számunkra, hiszen a negyedszázaddal korábbi munkát is új, friss szemmel kell nézni és modern szemlélettel kell átalakítani. Mindezt úgy kell végeznünk, hogy a tevékenységünk szigorúan intézmény-specifikus legyen, és közben nem veszítjük szem elől az alapfeladatunkat, hiszen a helytörténetírás kutatóhelyeként és mühelyeként a források örzése, feldolgozása és megismertetése maradt a legföbb célunk és kötelességünk. 


\section{Tudományos tevékenység}

A levéltárban folyó kutatás leginkább a régiót érinti, így mondhatnánk, hogy lokális, amely azonban visszatükrözi az általános történelmi folyamatokat, természetesen a helyi specialitásokkal. Minthogy a forrásfeltárás és -közlés nem tartozik a népszerü történelmi olvasmányok közé, ezért az a feladatunk, hogy azokat a nagyközönség számára érthetö és érdekes formában tudjuk megmutatni. Erre lehetőséget nyújt a két évtizede folyamatosan megrendezett nemzetközi konferenciánk, a levéltári napok programsorozata is.

\section{1. Nemzetközi Levéltári Napok}

A Nyíregyházán müködő levéltár sajátos helyzetben van, hiszen a gyüjtőkörébe tartozó megyék többségét a történelem viharai megtépázták, egy részük a határon túlra került. Így a régiókutatás a nemzetközi kapcsolatok érvényesítése, a romániai, kárpátaljai és szlovák közgyüjteményekkel, kutatóintézetekkel, egyetemekkel való szakmai együttmüködés nélkül elképzelhetetlen. A kialakított kapcsolatok nemcsak arra teremtenek módot, hogy a Szatmár, Bereg, Ung, Ugocsa és Kővár vidék múltját kutató levéltárosok, történészek, egyetemi, főiskolai oktatók, néprajzosok, muzeológusok, amatőr kutatók Nyíregyházán a levéltári nap keretében mondhassák el legújabb kutatási eredményeiket, hanem arra is, hogy a 2. napi programban személyesen meglátogathassunk egy-egy, számunkra fontos közgyüjteményt. Ezeken a szakmai utakon olyan helyeken fordultunk meg, ahova magánemberként nehezen jutunk el, pedig az őrzött iratanyag miatt nélkülözhetetlenek egy-egy kutatásban.

A levéltári napok iránt fokozódó az érdeklődés, a jelenlévők száma minden évben meghaladja a száz föt. Az elmúlt negyedszázad alatt a rendezvénynek kialakultak a hagyományos programelemei. Ezekben helyet kaptak a levéltári iratanyag bemutatásán belül az ajándékozással hozzánk került dokumentumok, valamint törekszünk a modern elektronikus segédleteknek, így a tematikánkhoz kötődő legújabb helyi dokumentumfilmeknek és adatbázisoknak a bemutatására is.

A tucatnyi érdeklődőt vonzó helytörténeti pályázatot együtt hirdetjük meg a városi társintézményekkel: a Jósa András Múzeummal, a Móricz Zsigmond Megyei és Városi Könyvtárral, a Nyíregyházi Egyetem Filozófiai és Történelmi Intézetével, valamint a Szabolcs-Szatmár-Bereg Megyei Honismereti Egyesülettel. A közzétételhez a közremüködők saját kommunikációs lehetőségeikkel járulnak hozzá. Célközönségünk az amatőr helytörténeti kutatók egyre szükülő csoportja. Pályázóink között az egyetemi hallgatók mellett vannak olyan idősebb emberek, akik a 20. századról saját élményeiket vagy szóbeli gyüjtésüket írják meg. A munkák a meghirdető közgyüjtemények adattárába kerülnek. A legjobbakat évkönyvünkben megjelentetjük, de egy-egy helytörténeti írás esetén felhívjuk a figyelmét a kutatásra az adott települések vezetőinek is. Ezt a kapcsolati szálat érdemesnek tartjuk a továbbiakban produktívabbá tenni és helybeli személyes bemutatókkal hozzájárulni a lokálpatriotizmus erősítéséhez. Ugyanakkor szükségesnek tünik a motiváció átgondolása is, akár országos kampányokkal, projektekkel, akár tekintélyesebb pályadíjaknak vagy a megjelenési lehetőségeknek a biztosításával, de ösztönözni kellene a helyi közösséget is arra, hogy bátorítsák a helytörténeti kutatást végzőket, mert a település történetének ismerete erős szál a lakosság valós és érzelmi helyhez kötésében.

A levéltár által szervezett programok hozzájárulnak az intézmény és gyüjteménye megismertetéséhez. A levéltárosok szakmai munkájának elismerése pedig annak a közbizalomnak az alapját képezi, amely fontosnak tartja a múlt írott emlékeinek megörzését és ezáltal iratajándékozásra is ösztönöz. Napjainkban rohamosan változik a bennünket körülvevő környezet és ezáltal a hagyományok szerepe is módosul. A korábban a családi iratok örzésére hivatott seniorok már nem minden esetben tudnak megfelelni az elvárásoknak, hiszen a modern lakásokban kevés hely jut a múlt emlékeinek. Emiatt a leglelkiismeretesebbek megnyugtató elhelyezést keresnek az őseiktől maradt tárgyaknak, iratoknak, így jutnak el mind többen a levéltárba. A személyes történelmet tükröző iratajándékok bemutatására mód nyílik a honlapunkon, de a köszönetet ünnepélyessé, nyilvánossá kell tenni. Erre a legjobb alkalomnak véljük a levéltári napok megnyitóján a saját készítésü Pro Archivo-emléklapunk átadását.

Hasonlóképpen honoráljuk szponzoraink támogatását. Bár nem bírunk nagy reklámértékkel, a levéltári napokat és a Múzeumok Éjszakájához kapcsolódó levéltári délutánunkat többen tartják kiemelt figyelemre érdemes programnak. Régi, állandó szponzoraink mellett minden évben vannak új, alkalmi támogatóink is. Külön gondot fordítunk arra, hogy a támogatók reklámjai a rendezvényhez illeszkedően jelenjenek meg, illetve más programjainkra való invitálással, ünnepi üdvözletekkel a kapcsolatunk egész évben folyamatos legyen. Ez mindannyiunk számára új, hiszen ilyen feladata korábban nem volt a levéltárosnak, de ma már nélkülözhetetlen. Az új kompetencia kialakításához jó lenne létrehozni a képzésformát is. 
Mivel mi még nem tanultunk kulturális menedzsmentet és PR-t, ezért autodidakta módon kell elsajátítanunk a tudnivalókat. A továbblépéshez azonban érdemes lenne elgondolkodni a szaktovábbképzésen.

A levéltári nap tudományos konferenciái tematikusak. Arra törekszünk, hogy a régiótörténeti előadások során a jelenlévők saját kollégáink mellett olyan előadókat ismerjenek meg, akiket a földrajzi távolságok miatt csak ritkán hallhatnak, illetve figyelemre méltó kutatási eredményeket értek el. A konferencia nyilvános. Meghívóját közzétesszük honlapjainkon és a médiában. A rendezvény iránti kiemelt figyelmet mutatja, hogy több rövid hír is megjelenik már szeptember elején, amely felhívja a figyelmet a hónap végén tartandó tanácskozásra. A programot megelőző televíziós és rádiós beszélgetések is motiválóak lehetnek, éppen úgy, mint a helyszín: a nemzetközi konferenciát általában a megye vezetése, alkalomadtán Nyíregyháza elöljárói látják vendégül dísztermükben. Míg első nap bárki ingyenesen látogathatja a rendezvényt, a második napi program regisztrációhoz kötött, hiszen a magyarországi vagy határon túli közgyüjtemények meglátogatása komoly szakmai és logisztikai elökészületet, pontos költségvetést igényel. Mivel a rendezvényeket saját költségvetésből finanszírozni nem tudjuk, a kiadásokat pályázatból - általában NKA támogatásból - fedezzük.

A tudományos konferencia helyhez és időhöz kötött. Ezen a kereten tágítottunk azzal, hogy felvételt készítünk az előadásokról, amelyet nyilvánossá teszünk a Videotóriumban. Ezáltal nem csak az írott és elektronikus média rövid híradását hallhatják az érdeklődők, hanem teljes egészében megismerhetik az elhangzottakat is. Jövőbeni feladataink egyike, hogy ezt úgy tegyük meg, hogy minden honlap-látogató számára nyilvánvaló legyen ez a lehetőség.

\subsection{Tudományos projektek}

A Magyar Nemzeti Levéltár és tagintézményei igyekeznek hozzájárulni az aktuális történetkutatás eredményeihez azzal, hogy tematikus forrásfeltárást végeznek, az évfordulókhoz és ünnepekhez kapcsolódóan pedig különböző programokat szerveznek. A közös tudományos projekteknek köszönhetően azonos szempontok alapján az egész országra kiterjedő kutatás folyik, amelynek eredményei a megyei levéltárakban és az országos rendezvényeken is nagy érdeklődésre tartanak számot. Ennek a munkának köszönhetően vált megismerhetővé több, eddig a levéltári raktárak mélyén lapuló forrás és adat a holokausztról, a világháborúkról és a hősi halált haltakról, az 1944-ben málenkij robotra elhurcoltakról, 1956-ról, a romák 20. századi történetéről. A reformáció évfordulója alkalmából is számos könyv jelent meg, diákprogramok sora hozta közelebb a múltat a jövő nemzedékéhez, illetve olyan nagyarányú digitalizálás van folyamatban, amely lehetővé teszi nemsokára az új közönségkapcsolati formát, a virtuális kutatást.

\subsection{Internetes megjelenések}

A levéltár alapfeladata továbbra is az, hogy a múlt írott forrásait őrzi a jövő számára, ugyanakkor lépést kell tartanunk a technikai fejlődéssel összefüggő újabb társadalmi elvárásokkal a közönséggel való kapcsolattartás legújabb csatornáin is. Mindezek miatt már évek óta fent vagyunk a világhálón. Korábbi statikus, leginkább híreket közlő honlapunkat már több mint egy évtizede dinamikusra cseréltük, illetve a Magyar Nemzeti Levéltár megalakulását követően elindult a megyei tagintézményeknek is helyet adó központ portál. Emellett három honlapot müködtetünk részben vagy egészen. Saját intézményi honlapunk, a szabarchiv.hu a leggazdagabb. Itt olvasható minden aktuális információ a levéltári történésekről, legyen az nyilvános rendezvény, állományunkat gyarapító iratajándékozás, új kiadványunk megjelenése, vagy éppen munkatársaink elismerése. Intézményünk elérhetőségéről, feladatáról és müködéséről, gyüjteményéről, vezetőiről éppen úgy informáljuk az érdeklődőket, mint kiadványainkról, szakkönyvtárunk állományáról, pályázatainkról. Elérhetőek saját fejlesztésủ adatbázisaink: a feudális összeírások, a térképek, a megyei tanácsi és vb jegyzőkönyvek. A Rákóczi-tárban forrásválogatást ajánlunk böngészésre. Hasonlóképpen szeretnénk felhívni a figyelmet a megyebeli iratokra, az 18481849-es dokumentumokra. Nyíregyháza dualizmus kori történetét is megismerhetik az érdeklődők az NKA támogatásával készült iratválogatás segítségével, mint ahogy a színfalak mögé is ezen a módon pillanthatunk be. A világháborúk, a holokauszt, a málenkij robot áldozatait név szerint tesszük közzé.

Igyekszünk gazdagítani digitális levéltárunkat is. Itt egyrészt azokról az iratokról készült mentett állományok kapnak helyet, amelyek valóságosan nincsenek az örizetünkben, hanem csak digitálisan kaptuk meg tulajdonosaiktól. Honlapunkról elérhető virtuális kutatószobánk képzeletbeli polcára felkerülnek még majd a levéltár kiemelt jelentőségü iratai, a fondok áttekintését segítő jegyzékek, kiadványaink. 
Másik honlapunkon, a nyirkuvik.hu-n a várostörténeti kutatás számára nyújtunk segítséget a legfontosabb források és a megjelent tanulmányok közzétételével és különböző információkkal. A harmadik honlap, az olvass-sokat.hu a könyvtári szolgáltatások színvonalát fejleszteni, támogatni szándékozó TÁMOP pályázat keretében jött létre. Itt a kuriózumnak számító iskolai évkönyveket jelentetjük meg, illetve az olvasni szeretők számára könyveket ajánlunk. Rendezvényeinkről hírt adunk a közösségi platformokon is.

\subsection{Könyvkiadás}

Amikor a tudományos kutatás eredményeinek megismertetésére elindult a kiadványozás, akkor a legnépszerübb forma a források és a feldolgozó tanulmányok, módszertani útmutatók közzétételére a könyvkiadás volt. Az első könyvek dr. Gyarmathy Zsigmond igazgató szerkesztésében 1976-tól jelentek meg. Az 1990 utáni évek jelentették a fénykort: volt olyan év, amikor több könyvet adott ki a levéltár (forrásközléseket, tanulmányköteteket, évkönyveket, iratjegyzékeket). A tematikai besorolás alapján kialakított és ma is élö öt sorozatban, valamint a sorozaton kívüliként megjelenö kötetek szerzői nemcsak levéltárunk munkatársai, hanem magyar és határon túli, régiónkkal foglalkozó kollégák.

A könyvek fontos kapcsolatteremtő szálak az intézmény, a szakemberek és a helytörténet iránt érdeklődők között. A legnagyobb könyvtárakba eljutó kiadványok mellett volt néhány árus példány is, de mivel nem voltak formailag mutatósak a kötetek, szinte csak a szakmával foglalkozók vásárolták. Két évtizede azonban figyelünk a tetszetős formai megjelenésre és arra, hogy minél szélesebb körben ismertessünk meg minden könyvünket a leendö olvasókkal. A közönséggel való minél szélesebb kapcsolat kialakítása érdekében a levéltárban szükebb körben tartott bemutatón kívül elvisszük azokra a településekre is a köteteket és a szerzőket, amelyek érintettek.

Kiadványaink költségét régebben az intézmény fedezte, manapság pályázatokból finanszírozzuk a munkálatokat. Az elöírásoknak megfelelve könyveink eljutnak a köz- és levéltári könyvtárakba, valamint a kutatóhelyekre, múzeumokba. Árusításukat a pályázati feltételek gyakran nem engedik meg, így kevésbé kerülhetnek az érdeklődő magánemberek polcaira. Minthogy azonban ma már az olvasási szokások is megváltoztak és a papír alapú könyvek mellett mindinkább terjednek a digitális kiadványok, valamint az internetalapú ismeretszerzés, mi is igyekszünk ily módon kompenzálni a vásárlásból kimaradókat: mind saját honlapunkon, mind a Hungaricana portálon elérhetővé tesszük a megjelentetett könyveket.

\section{Diákprogramok}

A száz éve még zárt, poros iratokkal zsúfolt levéltár a 20. században a nemesség- és származás igazolás révén vált ismertebbé. A század végén azonban már egyre többen fordultak meg az intézményben a munkában eltöltött éveikről, iskolai tanulmányaikról, házaik építéséről vagy a kárpótlási eljárásokhoz szükséges dokumentumokról kérve másolatokat. Az ügyviteli érdeklődő mellett nőtt a kutatók száma is, és a közművelődési rendezvényekre néha a szülők, tanárok gyermekeiket, diákjaikat is elhozták. Ez bátorított bennünket arra, hogy a programszervezést célirányosan kiterjesszük a diákokra is. A történelem megértéséhez, a lokálpatrióta kötődés kialakításához ugyanis már diákkorban meg kell ismertetni a forrásokat. Szem előtt tartva a kockázati tényezőket (azt, hogy a levéltárban lévő iratok egyediek, tehát csak a legnagyobb felelősségvállalás mellett forgathatóak, illetve állományvédelmi okokból használatuk korlátozott és szennyezettségük miatt nem is ajánlott), olyan programokat terveztünk az iskolások számára, amelyek interaktív módon hozzák közel a történelmet. A diákokkal történő kapcsolatteremtés formái a leggyakrabban módosulók, mivel igyekszünk megfelelni tartalomban és formában az aktuális igényeknek és elvárásoknak.

\subsection{Levéltári foglalkozások}

\subsubsection{Levéltári Esték}

Az első levéltár-pedagógiai kísérletünk a Levéltári Esték rendezvénysorozat volt, amelynek keretében minden hónapban egy csésze tea és néhány keksz mellett ismeretterjesztő előadások segítségével mutattunk be egy-egy forrást, amit eredetiben is megtekinthettek az érdeklődők. A résztvevők többsége gimnazista volt, így az ő tananyagukhoz igazítottuk a tematikát. Az évet mindig 1-1 távolabbi közgyüjtemény meglátogatásával zártuk. Jártunk az MNL Országos Levéltárában, a Széchenyi Könyvtárban, a Debreceni Déri Múzeumban, a sátoraljaújhelyi levéltárban. Az egy évtizeden át futó 
programsorozat záró akkordjában a tudományok és müvészetek világában kalandoztunk a források segítségével. Ezeket az esteket a helyi televízió is rögzítette és néhány évig folyamatosan müsoron tartotta.

\subsubsection{Tematikus foglalkozások}

A pedagógusok munkájának hatékonyabb szervezéséhez az alábbi tematikus óraajánlatunkat kínáljuk, minden alkalommal aszerint formálva a foglalkozást, hogy mire szeretné a szaktanár leginkább ráirányítani a figyelmet. Az órakínálat a többi diákprogramhoz hasonlóan elérhető honlapunkon a Diákoknak link alatt.

\section{Ajánlott témák:}

$>$ „Kincsek” a levéltárban (oklevelek, címerek, pecsétek) - A levéltár másfél száz oklevelének, a címerek és pecsétek típusainak a bemutatása.

$>$ Reformkori pillanatok (Kölcsey, Kossuth levelek) és az 1848-as forradalom írott forrásai - A reformkor gondolatvilágának, divatjának, szokásrendszerének bemutatása, 1848 eseményei a megyében

$>$ Hétköznapok, ünnepnapok és a szociális gondoskodás formái a 19-20. században - A különböző korszakok mindennapjainak, az országos/helyi ünnepeknek a története, az ezekhez kapcsolódó szokásoknak, valamint az alapítványok, egyesületek munkáinak bemutatása

$>$ Rákóczi nyomában - rendhagyó történelem órák a levéltárban - A rendhagyó történelem órákon a szabadságharcot korabeli források és multimédiás anyagok segítségével mutatjuk be.

$>$ II. Rákóczi Ferenc és Szabolcs, Szatmár, Bereg vármegye - A foglalkozáson a diákok megismerhetik Rákóczi és a három vármegye kapcsolatát, a szabadságharc helyi eseményeit, valamint a Rákóczi körül kialakult kultuszt és a néphagyományunkban betöltött szerepét. Bemutatjuk a Szabolcs-Szatmár-Bereg Megyei Levéltár Rákóczi-korról őrzött eredeti írásos emlékeit (vármegyei jegyzőkönyvek, iratok, Rákóczi pátensei stb.), valamint a Magyar Országos Levéltárban és más közgyüjteményben őrzött Rákóczi-kincseket.

$>$ Valós és virtuális várostörténeti séta - A foglalkozáson források segítségével kísérjük végig Nyíregyháza várossá fejlődését, a bokortanyák alakulását, az ott élők munkáját, mindennapjait, a városi társadalomban elfoglalt szerepük változását. A városközpontban tett séta során a szobrok és emlékjelek nyomán haladva a jelenben is felfedezzük a múltat.

$>$ Ki vagyok? - Családi emlékezet - Saját magunk megismeréséhez, a sikeres önmegvalósításhoz a múlt feltárásán keresztül vezet az út. Az ősök tiszteletéhez nélkülözhetetlen megismerésük. A foglalkozás célja a genealógiai alapismeretek és a kutatás módszertanának bemutatása.

$>$ Használd a könyvtárat! - Levéltári óra keretében mutatjuk be szakkönyvtárunkat, hasznos tanácsot adva a szakirodalom kereséséhez és könyvtárhasználathoz is.

> Várak Magyarországon az 1700-as évek elején (különös tekintettel Szabolcs, Szatmár és Bereg vármegyékre - vendégelöadó) A foglalkozáson bemutatjuk a törökkori végvárrendszert, a 16-17. századi várépítészetet, a diákok bepillantást nyerhetnek a végvári életbe. A II. Rákóczi Ferenc életében és a szabadságharcban fontos szerepet játszó várak hangsúlyt kapnak a foglalkozáson, különös tekintettel az egykori Szabolcs, Szatmár és Bereg vármegyékre.

\section{Évfordulós (reformációs) foglalkozások:}

$>$ Protestáns nagyasszonyok - Két erdélyi fejedelemasszony, Lorántffy Zsuzsanna és Bornemissza Anna életének, tevékenységének bemutatása.

$>$ Evangélikus iskolák és tanitók a 19. századi Nyíregyházán - Az 1753-tól érkezett városalapítók többségét alkotó evangélikusok gyermekeinek iskolával, tantárgyaival, tanítóival ismerkedhetnek meg a foglalkozás résztvevői.

> „Utazás Wittenbergbe” - A reformáció kezdetének ötszáz éves évfordulója alkalmából a Magyar Nemzeti Levéltár (MNL) valamennyi intézménye reformációs témájú levéltári órával várja az érdeklődőket két korcsoportban. Az általános iskolák felső tagozatos tanulóinak, valamint középiskolás diákoknak szóló foglalkozások a jubileumi év folyamán zajlanak.

\subsection{Honismereti tábor}


A Szabolcs-Szatmár-Bereg Megyei Honismereti Egyesülettel közösen szervezett napközis táborban naponta más-más szakember vezette be a gyerekeket a helytörténeti kutatás rejtelmeibe.

\subsection{Múzeumfalui programnapok}

A Sóstói Múzeumfalu gyermeknapi programjának kínálatát színesítette több éven át a Levéltár-ház genealógiai, heraldikai foglalkozásainak sorozata.

\subsection{Közös kutatás}

A málenkij robotra elhurcoltak nevének és sorsuknak feltárására indított tudományos kutatásba és feldolgozásba bekapcsolódott a Zrínyi Ilona Gimnázium egy kutatótanára és diákja is. Az oral history gyűjtés eredményeit rendhagyó történelemóra keretében ismertették meg. A szemtanúkkal, utódokkal folytatott beszélgetésröl rövidfilmet is készítettek, amely felhasználható a történelemoktatásban.

\subsection{Diákkonferencia}

A város gimnáziumainak tanárai és diákjai közremüködésével a Nyíregyházi Kutatódiákok Társadalomtudományi Konferenciáján mutatjuk be a legsikeresebb pályamunkákat, hasznos tanácsokat adva az érettségire felkészülő társaiknak.

\subsection{Vetélkedök}

A diákokat próbáljuk egyénileg is motiválni, de buzdítjuk őket a kisebb-nagyobb csoportokban való felfedezésre is. Elsősorban olyan pályázatokat írunk ki, amelyek elkészítéséhez családi beszélgetésre, saját múltjuk, őseik és lakókörnyezetük megismerésére van szükség. Az információszerzés módjának megváltozásához igazodva a gyüjtő-feldolgozó munkához fel kell, hogy használják az infotechnikai eszközöket is.

\subsection{Internetes tananyagok, játékok}

A Z generáció számára E-learninges tananyagokat készítettünk a városbeli középiskolai tanárok segítségével. Arra alapozva, hogy a gyerekek szívesen tanulnak számítógépes játékok segítségével, próbaképpen két saját fejlesztésü játékunkkal szeretnénk érdeklődést kelteni a családtörténeti kutatás és a régió nagy jelentőségü családjának, a Károlyiaknak a története iránt.

Ebben az évben készült el a levéltárat bemutató interaktív, diákoknak szóló kisfilmünk, amit levéltári foglalkozásokon szívesen fogadnak a gyerekek.

\subsection{Külsös rendezvények}

A levéltár által őrzött iratok egyediek, állományvédelmük miatt csak a levéltárban tekinthetőek meg. A mai technikának köszönhetően azonban digitalizált változatuk illusztrációként bárhol felhasználható. Ezáltal azokban az iskolákban is megismerhetik a diákok a legfontosabb dokumentumokat, ahol kollégáink elöadásokat tartanak. Főként évfordulós rendezvényeken kapunk erre felkérést a vidéki középiskolákból. Közremüködtünk a kárpátaljai elhurcolást bemutató kiállításnak, az MNL világháborús és reformációs, valamint a heidelbergi levéltár kiállításának a diákokkal való megismertetésében.

\subsection{Pedagógus szakmai rendezvények}

A helytörténet iránt érdeklődő, vagy ehhez kapcsolódó tárgyat oktató tanárok számára alkalmanként rendezünk szakmai ankétokat a források szerepéről és a levéltár oktatási folyamatba való bekapcsolódásáról a KLIK-kel, a Szabolcs-Szatmár-Bereg Megyei Honismereti Egyesülettel közösen, valamint a Kutatói Kerekasztal programjában.

\section{Ismeretterjesztő előadások}

Több, mint negyedszázada a személyes kapcsolatok kialakítása tünt a legjobb megoldásnak ahhoz, hogy kitárjuk az addig misztikusnak és zártnak tủnő levéltár ajtajait, megmutassuk, hogy milyen forrásokat örzünk és ezekben milyen információk rejlenek a múltról. A mintavételezésnek tekinthetỏ Levéltári Esték „utódrendezvényei” már olyan tematikus előadásblokkok, amelyeket nem iskolai módszertani segédanyagnak, hanem minden korosztály számára új információkat vagy szintetizálásra törekvő összefoglalókat tartalmazó ismeretterjesztő sorozatnak szántunk. 


\section{1. „Múltról mindenkinek” sorozat}

Az elnevezésében is a sokszínü megközelítésre utaló programsorozat város-, megye-, családtörténeti előadások, beszélgetések mellett évfordulós megemlékezésekre, kötetbemutatókra is megfelelő keretül szolgál. Általában havonta egy rendezvényünk van hétfőnként, mivel 30 érdeklődőnél többet csak a kutatóteremben tudunk fogadni, ahol ezen a napon van szolgáltatási szünnap. Előadóink alkalmanként saját kollégáink, legtöbb esetben azonban olyan hazai és határon túli történészek, levéltárosok, muzeológusok, irodalom-, müvészet- és müvelődéstörténészek, tanárok, papok, jogászok, akik vagy a mi iratainkban kutatva találtak közzétételre érdemesnek itélt adatokat, vagy más közgyüjteményekben folytatott munkájuk, esetleg saját gyüjtéseik eredményeit foglalják össze a rendelkezésükre álló szük órában. A program résztvevői között köszönthettünk már olyanokat is, akik jelentős mennyiségü és kiemelkedő történeti értékü iratokat ajándékoztak nekünk.

\section{2. „Beszélgetések a 20. századról” sorozat}

A közelmúlt iránti érdeklődés motiválta a programsorozat indítását, amellyel az volt a célunk, hogy ráirányítsuk a figyelmet közelmúltunk szemtanúira, a témával foglalkozó levéltárosokra, történészekre, továbbá a forrásalapú megközelítésekre, elemzésekre. Az elmúlt évtizedekben áttekintettük a századforduló fejlődését, bepillantottunk az 1905-ös választásba, virtuális sétát tehettünk a város ez időben épült, ma is álló házai között, megismerkedhettünk a 2. világháború csatatereinek borzalmaival, a hátország életével, városaink bombázásával, a holokauszt, a málenkij robotra való elhurcolás szörnyüségeivel, a csehszlovák-magyar lakosságcsere forrásaival és emlékeivel, az 1950-es évek félelmeivel, 1956-tal, a Kádár-rendszer sajátosságaival, az 1990-es rendszerváltozás előzményeivel és folyamatával. Vendégeink voltak a szemtanúk mellett az Állambiztonsági Levéltár, a MNL Országos Levéltára és a határon túli társintézményeink tudományos munkatársai. Ezeken az alkalmakon a felnőtt érdeklődők mellett rendszerint sok volt a középiskolás diák, reprezentálva, hogy a karnyújtásra lévő történelmet még nem foglalták össze olyan szintetizáló munkák, amelyek teljes képet adnának a 20. századi történésekről, és így több olyan esemény van még, amelyről újabb és újabb ismeretet igényelnek a múlt iránt érdeklődők.

\section{3. „Arcok és könyvek a történettudomány köréböl”}

A sorozatot a könyvtárfejlesztést támogató TÁMOP pályázat keretében indítottuk el. Az volt a célunk, hogy a Nyíregyházán és a megyében élők személyesen megismerhessék azokat, akiknek a munkáikat forgatják. Szerettük volna továbbá ráirányítani a figyelmet azokra a szakkönyvekre, amelyek új megközelítésben, olvasmányos stílusban, információgazdagon, forrásalapú feldolgozással járulhatnak hozzá ismereteink bővítéséhez, szemléletünk formálásával. Ehhez kívántunk még pluszként hozzájárulni a szerzővel folytatott beszélgetéssel. A könyvek rövid ismertetésére, a beszélgetés vezetésére tudományos munkatársaink vállalkoztak. Vendégeink voltak nyíregyházi, debreceni és budapesti levéltárosok, tanárok, történészek.

\section{Társintézményekkel közös programok}

\subsection{Egyházi levéltárak}

Nyíregyházán két egyházi levéltár müködik. A görögkatolikusok és az evangélikusok is számíthatnak szakmai segítségünkre. Mindkét levéltárba szervezünk látogatásokat, amelyeken diákok és felnőttek egyaránt részt vesznek. A fenntartó egyházak vezetőivel is kapcsolatban vagyunk. Az idén a reformációs projekt keretében lehetőséget adtunk az evangélikus mellett a református gyülekezeteknek is a levéltárban történő bemutatkozásra. A rendezvényre a gyülekezet tagjai is ellátogattak a levéltárba.

\subsection{Múzeum}

A szomszédos Jósa András Múzeummal 1972-től 1999-ig, amíg át nem költöztünk a levéltár jelenlegi helyére, egy épületben müködtünk, és minden rendezvényünket a múzeum nagytermében tartottunk. A személyes kapcsolatnak és a gyüjtemény hasonlóságának köszönhetően is éveken át együtt szerveztünk több kiállítást, konferenciát. A Múzeumok Éjszakájához Levéltárunk délutánja c. programunkkal csatlakozunk. Minthogy ilyenkor a szomszédos Jósa András Múzeum rendkívül gazdag rendezvénysort kínál, mi ezekhez illeszkedő kamarakiállítással, rövid, érdekes helytörténeti előadással, 
gyermekvetélkedővel színesítjük a programot. A Múzeumok Öszi Fesztiváljába 2017-ben kapcsolódtunk be, ennek keretében éjszakai lámpás levéltári sétán vehettek részt az érdeklődők. A múzeum munkatársai állandó kutatóink, előadóink, mint ahogy a mi munkatársaink is előadásokat tartanak, kiállítást nyitnak meg a múzeumban.

\subsection{Könyvtárak}

A helybeli szakkönyvtárakkal az évek során konstruktív szakmai kapcsolat alakult ki. Ebben sokat segített a társintézményekkel szervezett közös programok sora, egymás személyes megismerése. A könyvtári szolgáltatásokkal kapcsolatos tapasztalatcsere, egymás informálása, jó tanácsokkal való ellátása ma már a mindennapi munka része. Szívesen hívjuk vendégkiállításra, bemutatkozásra a könyvtárakat, mint ahogy örömmel veszünk részt a digitalizálásban élen járó könyvtáros kollégákkal szakmai megbeszéléseken, fórumokon. Pályázatokon kívüli közös munkánk szép eredménye a Nyírvidék címü folyóirat digitalizálásra való előkészítése, valamint a könyvhéten, könyvtári bemutatkozáson való megjelenésünk, részvételünk.

\subsection{Kutatói Kerekasztal}

Két évtizeddel ezelőtt a Jósa András Múzeum, a Sóstói Múzeumfalu és az akkori tanárképző főiskola, ma egyetem történelem tanszékével közösen létrehoztuk a Kutató Kaszinót, amely változó helyszíneken adott lehetőséget a tudományos kutatással foglalkozóknak a találkozásra, szakmai eszmecserére. Bár néhány alkalom után a személyi változások, intézményátalakulások, anyagi nehézségek miatt a „Kaszinót bezártuk", de a kutatások megismerésének igénye továbbra is fennállt, így szerényebb körülmények között, a levéltár kutatótermében alkalmanként összehívjuk a Kutatói Kerekasztalt. A résztvevők körét tágítottuk a könyvtárosokkal, vidéki múzeumi szakemberekkel, kutatótanárokkal és a figyelemre méltó eredményeket elért amatőr kutatókkal. A rendezvényen az eredmények mellett szó esik a célokról és módszerekröl is.

\section{Felsőoktatási intézményekkel kialakított kapcsolatok}

\subsection{Nyíregyházi Egyetem}

A levéltár tudományos munkatársai hosszú éveken át óraadók voltak a főiskola történelem tanszékén. Bár az oktatási rendszer átalakult és ez a kapcsolat megszünt, a ma már egyetemként müködő intézmény továbbra is szívesen látja a levéltárosokat előadóként, szekcióvezetőként konferenciáin, mint ahogy az egyetemi oktatók is örömmel fogadják el a levéltár felkérését a különböző rendezvényekre, hallgatók számára szervezett programokra.

\subsection{Szent Atanáz Görögkatolikus Hittudományi Föiskola, Nyíregyháza}

A főiskola nem csak oktatási intézmény, hanem kutatóközpont is, amely élenjár a hazai és határon túli közgyüjteményekben örzött források feltárásában és közreadásában. Ezt a munkát érdemes minél szélesebb körben megismertetni, ezért örömmel mutatjuk be valós és virtuális formában kiadványaikat és azok szerzőit és veszünk részt tudományos rendezvényeiken.

\subsection{Debreceni Egyetem}

Az egyetem Történelmi Intézetéhez számos szál köti levéltárunkat. Több kolléga tanult itt és szerzett vagy szerez minősítést a doktori iskolában. Rendszeresen kapunk meghívást rendezvényeikre, felkérést köteteikben megjelenő tanulmányok írására. Az egyetem oktatóira előadóként, helytörténeti tanácsadóként, szerzőként is számíthatunk. Szakmai munkánkat segítik gyakornokok ajánlásával, közönségkapcsolatainkat pedig azáltal is bővítik, hogy hallgatóik számára minden évben szerveznek levéltár ismertető sétát.

\subsection{Debreceni Egyetem Egészségügyi Kar, Nyíregyháza}

A városban müködő intézmények közül a karral ritkán vannak közös programjaink, de az 1998-ban rendezett tematikus konferencia alapot jelent a továbbiakban is az esetleges együttmunkálkodáshoz.

\subsection{Rákóczi Ferenc Kárpátaljai Magyar Föiskola, Beregszász}

A Beregszászban müködő főiskola a kárpátaljai magyarság tudományos kulturális centruma. Tanáraival személyes és szakmai kapcsolatunk is kiváló. Helytörténeti kutatásaikat rendszeresen osztják meg velünk 
különböző rendezvényeinken, mint ahogy mi is gyakran veszünk részt konferenciáikon, kulturális, tudományos rendezvényeiken, amelyeken nemcsak hallgatóikkal, hanem helybeli kutatókkal, tanárokkal, lokálpatriótákkal is találkozhatunk.

\section{Szakmai együttmüködések:}

6.1. Levéltárak, szakmai egyesületek programjain való részvétel

A szakmai továbbképzésnek sok formája létezik. Egyik meghatározó irányvonalnak gondoljuk az országos szakmai szervezetek programjaiba való bekapcsolódást, ami az MNL megalakulásával még inkább hangsúlyozottá vált. Ezeken a rendezvényeken van módunk találkozni az ország különbözö intézményeiben dolgozó kollégákkal és tapasztalatot, gondolatot cserélni a szakmai kérdésekröl. Hasznosak a szakmai egyesületeink által szervezett könyvbemutatók, piknikek, konferenciák, vándorgyülések.

$\mathrm{Az}$ újdonságok és más megközelítési módok megismerésére, sőt a saját levéltárunk, kutatási eredményünk megismertetésére is jó alkalom a megyei és országos könyvtárak, múzeumok, egyetemek meghívásainak elfogadása révén rendezvényeiken előadóként vagy hallgatóként való részvétel.

\subsection{Kormányhivatal és önkormányzatok}

A levéltár az iratok örzése mellett ellátja a napjainkban keletkezett iratok felügyeletét is. Ezáltal szoros kapcsolatban van a hasonló jogkörrel rendelkező kormányhivatallal és az állami iratképzőkkel. A hivatalos ügyintézés során a közigazgatás és a kulturális élet vezetöivel, prominenseivel kötött ismeretség hozzájárul a helytörténeti kutatást támogató programjaink megvalósításához, a helybeliek kutatásának segítéséhez, a településtörténeti kiadványok megjelentetéséhez és különböző helyszíneken való bemutatásához. Közönségkapcsolati szálaink erősödnek, amikor a helyi konferenciákon tartunk előadást, ünnepeken, avatókon mondunk emlékbeszédet, megnyitunk egy kiállítást. Mindezekkel a cél az lenne, hogy a megyetörténet feltárásába minél több mikroközösség kapcsolódjon be.

\section{A közönségkapcsolatok bővítését segítő pályázatok}

\subsection{Uniós pályázatok}

Néhány évvel ezelőtt a helybeli, akkor még főiskolaként müködő intézmény szakkönyvtára projektvezetésével olyan TÁMOP pályázat részesei lettünk, amely széles teret biztosított a közönségkapcsolat bővítéséhez. A könyvtári katalógus adatbázisba vitele mellett lehetőséget kaptunk konferenciák, előadások, beszélgetések szervezésére és egy olyan közös honlap müködtetésére, amelyen könyveket ajánlhatunk, bibliográfiákat közölhetünk, valamint itt tehető közzé a sokak által érdeklődésre számot tartó iskolai értesítők digitalizált változata is.

A másik uniós pályázat, a TIPOP az iskolán kívüli tanulás infrastruktúrájának kialakítását támogatta. Segítségével kialakultak, korszerüsödtek az intézmény közönségkapcsolati terei, megújult az infokommunikációs eszközparkunk és ma már a fogyatékkal élők számára segítséget jelentő eszközök (indukciós hurok, Jaws stb.) is rendelkezésre állnak. A modern oktatóterek létrejöttével olyan programokat tudunk szervezni, amelyek sem térben, sem időben nem akadályozzák a napi szakmai munkát.

\subsection{Hazai pályázatok}

Ma már nélkülözhetetlenek a szakmai munkát segítő pályázatok. A mi speciális tevékenységünket leginkább az NKA Közgyüjteményi Kollégiuma támogatja. Segítségükkel valósulhatnak meg a közmüvelődési programok költséget igénylő rendezvényei, jöhetnek létre a honlapunkon elérhető adatbázisaink és jelenhetnek meg azok a könyvek, amelyek eljutnak a szak- és közkönyvtárakba, a kutatóhelyekre, iskolákba is.

Évfordulós projektjeinket (holokauszt, málenkij robot, reformációs megemlékezések) egyedi pályázatok támogatásával valósítottuk meg.

Figyelemmel kísérjük azokat a pályázatokat is, amelyek infrastrukturális fejlesztésre adnak módot, illetve lehetővé tennék a ritkán megforduló célcsoportoknak a minél intenzívebb bevonását (fogyatékkal élők, pedagógusok, értelmiségiek, az aktív korosztály hely- és családtörtént iránt fogékony tagjai, kulturális egyesületek, klubok stb.). 


\section{Kommunikáció}

Rendezvényeinkről több kommunikációs csatornán is igyekszünk hírt adni. Programjaink saját meghívóját a levéltárba érkezők személyesen kapják meg, a PR listánkra hivatalból felkerültek és önként feliratkozottak pedig e-mailben. Honlapjainkon a rendezvényről elötte rövid hír, utána pedig hosszabb beszámoló jelenik meg. A helyi írott és elektronikus média érdeklődését is felkeltik általában programjaink. A rövid tudósítások mellett hosszabb hírek, beszélgetések, interjúk is megjelennek rólunk.

Szerény, házilag készített szórólapokkal, aktuális apró figyelmességekkel (könyvjelző, képeslap) is igyekszünk felhívni a figyelmet az intézmény tevékenységére, gyüjteményére.

\section{Jövőkép}

Az MNL szorgalmazza a nyitott és szolgáltató levéltárrá válást, az intézményi tudományos projektekbe, a helyi közmüvelődésbe való bekapcsolódást, a közönségkapcsolati lehetőségek feltárását és kihasználását. Nagy kérdés számunkra, hogy a több száz év alatt formálódott szakmai feladatokat miként alakítsuk át a mai igényeknek megfelelően, milyen formát válasszunk a kommunikációhoz és a Neumanngalaxis figyelembe vételével milyen új hozzáférési lehetőségekben kell gondolkodnunk. A levéltár paradigma váltást él meg napjainkban. A számítógép nélkülözhetetlenné válik nemcsak az iratokhoz készítendő segédletekben, hanem az iratképzésben és az archiválásban is. Miközben kötelességünk gondoskodni a hozzánk került, több évszázada keletkezett, pergamenre írt forrásokról, a savasodó papír alapú dokumentumokról, nagy figyelmet kell fordítanunk a raktárhiány miatt át nem vett iratokra, azok pusztulástól való megóvására, ugyanakkor ki kell alakítani az új munkamódszereket az elektronikusan keletkezett iratok mentésével, tárolásával, későbbi használatával kapcsolatosan. Mindehhez a társadalom, az állam támogatására van szükség. A minél szélesebb közönséggel kialakult kapcsolat biztosítja azt az ismertséget, aminek eredménye révén kialakulhat munkánk közmegbecsülése, az általunk örzött iratok jelentőségének felismerése és az a közös tenni akarás, amely a jövő számára meg akarja menteni a múlt emlékeit.

Kulcsszavak:

tudományos szintü ismeretterjesztő programok Public Lecture Series

levéltár-pedagógia Education

E-learning e-Learning

honlapok és adatbázisok - Websites and Databases

médiajelenlét Press 


\title{
Közönségkapcsolati lehetőségek az MNL SZSZBML-ben
}

(absztrakt)

\begin{abstract}
A Magyar Nemzeti Levéltár Szabolcs-Szatmár-Bereg Megyei Levéltára fontos feladatának tartja az iratok megörzése mellett azok megismertetését is. Ennek érdekében több mint három évtizeddel ezelött olyan programokat indított el, amelyek lehetőséget adnak a régió történetét feldolgozó kutatók és kutatások, valamint a legfontosabb dokumentumok bemutatására. A rendszeres rendezvény sorozatok, a megjelentetett kiadványok ismertté tették a levéltár munkáját. Az iskolákkal, egyetemekkel, múzeumokkal, könyvtárakkal kialakított szakmai kapcsolatok mellett az intézmény igyekszik figyelemmel lenni napjaink iratképzőire, a helytörténet iránt érdeklődő szélesebb nagyközönségre is. Az információátadásban és -cserében napjainkban egyre nagyobb szerep jut a számítógépnek: a levéltár is több honlapot üzemeltet, fent van a közösségi oldalakon, a forrásokat adatbázisok segítségével teszi felhasználóbaráttá.
\end{abstract}

\section{PR Opportunities for MNL SZSZBML}

Hungarian National Archives Szabolcs-Szatmár-Bereg County Archives is committed not just to preserving historical documents but also to presenting them. With this intention for more than three decades ago there have been started programs to present researchers and researches of our region, as well as to present the most valuable archival documents. Our regular public programs, publications made the Archives' work well-known. Besides professional partnerships with schools, universities, museums and libraries, we also try to focus on today's recordcreators and on general public interested in local history. Due to increasing role of computers in delivering and changing data, our Archives runs more websites, uses social media platforms and makes archival documents user-friendly available through databases. 